\title{
Introduction to the special edition on Serving those Serve
}

This special edition of Online Learning focuses on research and best practices for serving military personnel. Military students can be found at almost every higher education institution (Ford \& Vignare, 2015; Cate \& Albright, 2015) in the US. The authors and editors share with the readers a range of articles which commence with a review of literature, and include articles on using technology effectively for online military learners, building a more comprehensive understanding of military students, helping military personnel successfully transfer to the role of students, and building academic programs designed for such students. These articles build a research base for current- generation military learners engaged in military service after September 2001. The military personnel increase since 2001 and the current downsizing leading to large veteran population has created a unique opportunity to build the research base and understanding of online military learners, online institutions and military learners in general.

Through the reviews of literature in several of the articles, it is clear that not enough scholarly research has been shared in the last decade about online military learners. Military personnel, military families and veterans have chosen online learning in great numbers during the last decade. Most military learners have characteristics similar to other non-traditional adult learners who have increasingly chosen online learning for the last decade and a half. Yet, as the reader will observe there are also very distinct differences in the online military population. These articles will help researchers and practitioners alike gain a more comprehensive picture of this student segment.

The special issue starts with, The Evolving Military Learner Population: A Review of the Literature from Ford \& Vignare. The review of literature is a welcome update for those serving the online military learner. The student focus is on current generation military learners who entered service post 9/11. The review synthesizes both scholarly and grey literature to update the readers on demographics, attributes, college experiences and academic outcomes. The authors frame the research with conceptual theories on adult learners' transition and persistence along with institutional responsiveness. Findings suggest that military learners were most similar to nontraditional, first generation learners. They faced additional challenges associated with service-connected injuries and disabilities. Like other nontraditional learners juggling work, family, and academic responsibilities, military learners have become increasingly reliant on online learning. These learners often faced more difficulty when attending campuses that predominately serve full-time or traditional 18 to 24 year old populations. The authors caution that due to the significant lack of research on online military learners that explicit comparative analysis is problematic.

Overall, current research suggested that military learners adapt and persist in college by drawing upon deeply engrained military traits and tendencies, including self-discipline, mission-first focus, and reliance on fellow military leaners (Ford \& Vignare). A few studies have suggested that institutional response support systems for military learners, such as offering customized services and courses online, contributed to learner satisfaction and persistence. Confirming these findings requires additional quantitative empirical research with larger and more precisely defined population samples. In addition, this review of literature also points to the need for nuanced and sophisticated analyses rather than simplistic face-to-face and online comparisons. The next set of articles on military learner research must focus on military learner retention models which consider learning modalities and institutional student supports needed to enhance success. Understanding the paths through multiple institutions is also important before the field will have generalizable information about military learners.

In the next study, An Analysis of Supports for Persistence for the Military Student Population, Mentzer, Black and Spohn studied the correlations of academic, financial, and social supports to the persistence of a military student population: veterans, active duty, and their families. The authors also contrasted these 
relationships with non-military students. The results confirmed the emphasis in the persistence literature on the importance of academic support mechanisms and noted its positive relationship to the military student population. This study furthers research on persistence and academic support necessary in online learning. The authors also found that institutional support was a key support mechanism. Recommendations include enhancing academic and institutional support for the military student population to reinforce their persistence.

Cate and Albright, in Supporting Student Veterans: Utilizing Game-Based Role-Plays with Virtual Humans to Build Military Cultural Competency and Helping Behaviors in Faculty and Staff focus us on some of the mental health issues that our military learners may need to deal with as they engage in higher education. To better support and retain the nation's current 950,000 student veterans, higher-education institutions are beginning to train faculty and staff to more effectively understand and meet the needs of these students. This study examines the impact of a new and innovative game-based virtual training simulation. Faculty and staff can role-play with emotionally responsive virtual student veterans to understand the unique value veterans bring to campus, anticipate obstacles faced in their pursuit of a college degree, learn effective tactics for managing challenging conversations and become familiar with the best practices for connecting student veterans exhibiting signs of psychological distress with appropriate support services. The article shares promising data about the impact of new role-playing technology to train faculty and staff.

Richardson, Ruckert and Marion in Planning for Veterans' Success! The Degree Map as an Advising Solution provide readers with more practical advice for working with military learners. The article argues that because of the expected influx of veterans attending college, it is critical that higher education anticipate the projected growth and proactively plan for these students' success. The experience of one institution is shared. The authors argue that veteran students often have difficulty interpreting university scheduling and thus frequently contact a small advising staff for course selection information. This study's findings suggest the degree map is a powerful tool to help students through class selection and sequencing. The degree map data provides transparency that will contribute to institutional and governmental monitoring for ongoing outreach to student veterans.

Cass and Hammond in their paper, Bridging the Gap: Technology and Veteran Academic Success presents yet another use of technology to support student veterans in college, and reinforces the notion of blending of high impact practices with technology to promote military learners academic success. The authors highlight the historical trends of student veterans in the academy and discuss the barriers to success for this unique population of students. Uvize software, an online mentoring and advising platform for student veterans, is reviewed along with the preliminary results from three institutions. This article further defines why student veterans are a special student population on our campuses who require unique services to support their overall academic success.

In Rules of Engagement: Considering Good Policy and Practice with Online Military Learners StarrGlass focuses on whether military learners may not stand out or be particularly distinctive from their nonmilitary peers in online distance learning environments. However, military learners do possess a degree of difference that needs to be recognized. The military learners seem to display two distinctive student personas that emerge in different situations. One of the personas, military learners exhibit is not particularly different from their non-military peers. This author has ten years' experience working with military learners and this article explains these different cultural perspectives, explores the negative impacts of stereotyping, and provides practical suggestions for harnessing the strengths of these learners in productive online learning.

In the Collins, Kang, Yelich Biniecki and Favor paper, Building an Accelerated Online Graduate Program for Military Officers, the authors share best practices about designing a program for military 
officers. Reflecting on the more than twenty years of experience in teaching and mentoring militaryofficer learners, this article describes the story behind the development of an accelerated online program. The authors share the challenges brought along with having military officers as part of our online classes, including unpredictable deployment schedules, unannounced military exercises, security concerns and military values and culture. The article shares how faculty addressed challenges with creative pedagogy and other strategies while still maintaining the rigor of the academic program.

Continuing with best practices research, the Keavney paper, A Core Course on Veterans' Health in an Online RN to BSN Program, discusses bachelor level program development spurred by national interest. The Joining Forces Initiative challenges nursing programs throughout the country to develop curriculum that addresses the unique healthcare issues facing veterans. One military-serving institution developed an online Bachelor of Science in Nursing (BSN) in which students acquire the knowledge that will help them to care for veterans in all areas of nursing practice. This article describes a retrospective evaluation of the effectiveness of a dedicated core curricular course in increasing awareness of the unique issues facing today's veteran. It also discusses whether nursing students gain an appreciation for their role in helping veterans gain access to available resources and achieve maximum health and wellness.

The final paper by Selber, Biggs, Chavkin, and Wright, Online Training for Working with Student Veterans: A Social Work Elective Course, describes one university's innovative approach with an elective course to prepare Masters of Social Work (MSW) students for practice with the military, veterans and their families. Developed as part of a university-wide veteran's initiative, this online course keeps the focus on the student veteran and uses best practices of online education. The authors share their strategies and make recommendations for future trainings.

The special issue contains a fresh set of research papers and best practices for institutions, administrators, faculty and staff serving military learners. The series of papers collected here provides new insights on military learners, with updated research, promising technologies, innovative programs and specialized courses. Yet, as noted there is pressing need for others to continue to build scholarship that focuses on serving those that serve. We challenge researchers in online learning to continue to share scholarship on this important student segment.

The Editors

Karen Vignare, University of Maryland University College

Kristen Betts, Drexel University

Kathryn Snead, American Association of State Colleges and Universities

Thomas Bailey, University of Maryland University College

Melissa Layne and Elizabeth Wallace, American Public University System

Acknowledgements

The editors would like to thank all the authors that submitted papers for this issue. The editors would also like to recognize the hard work of the Online Learning Journal editors and staff. As a team, these guest editors poured over many articles, trying to build a new generation of research that others could learn from in the online learning field. Each editor brought to the team a comprehensive understanding of either online and or military learners. The special issue is a culmination of those efforts and their teamwork, resulting in an important contribution to the field of research on online military learners. 